\title{
Rekomendacijos
}

\section{Lietuvos suaugusiųjų sunkios astmos diagnostikos ir gydymo rekomendacijos 2017}

\author{
KRISTINA BIEKŠIENE் ${ }^{1}$, KĘSTUTIS MALAKAUSKAS ${ }^{1}$ (redaktorius), EDVARDAS DANILA ${ }^{2,3}$, \\ ROLANDAS ZABLOCKIS ${ }^{2,3}$, AUDRA BLAŽIENÉ2, ${ }^{2}$, SKAIDRIUS MILIAUSKAS ${ }^{1}$, \\ RAIMUNDAS SAKALAUSKAS ${ }^{1}$, VIRGINIJA ŠILEIKIENE் $\dot{E}^{2,3}$ \\ ${ }^{1}$ LSMU MA Pulmonologijos klinika, ${ }^{2}$ Vilniaus universitetas, ${ }^{3}$ Všt Vilniaus universiteto ligoninès \\ Santariškių klinikų Pulmonologijos ir alergologijos centras
}

\section{Santrumpos}

ACT - Astmos kontrolès testas

ACQ - Astmos kontrolès klausimynas

AKFI - angiotenziną konvertuojančio fermento inhibitoriai

ANCA - antibranduoliniai citoplazminiai antikūnai

ATS - Amerikos krūtinès draugija

DAI - dozuoto aerozolio inhaliatorius

DMI - dozuotų miltelių inhaliatorius

ERS - Europos respiratologų draugija

FeNO - frakcinė iškvepiamo azoto oksido koncentracija

$\mathrm{FEV}_{1}$ - forsuotai iškvepiamas tūris per pirmąją sekundę

FVC - forsuota gyvybinè plaučių talpa

GERL - gastroezofaginio refliukso liga

GINA - Pasaulinè astmos iniciatyva

GGK - geriamasis(-ieji) gliukokortikoidas(-ai)

IgE - E klasès imunoglobulinas

IGK - ikvepiamasis(-ieji) gliukokortikoidas(-ai)

IL-5 - interleukinas penktas

IVBA - ilgo veikimo ikvepiamasis(-ieji) $\beta_{2}$-agonis$\operatorname{tas}(-\mathrm{ai})$

IVMB - ilgo veikimo ịkvepiamasis muskarino receptorių blokatorius

$\mathrm{HbCO}$ - karboksihemoblobinas

LOPL - lètinè obstrukcinè plaučių liga

NO - azoto oksidas

$\mathrm{PEF}$ - didžiausias iškvèpimo srovès greitis

TLK - Tarptautinè ligų klasifikacija

TVBA - trumpo veikimo įkvepiamasis(-ieji) $\beta_{2}$-agonistas(-ai)

TVMB - trumpo veikimo ikvepiamasis(-ieji) anticholinerginis(-iai) vaistas(-ai)

\section{SUNKIOS ASTMOS SAMPRATA}

Sunki astma yra didelè sveikatos priežiūros bei socialinè ir ekonominè problema visame pasaulyje, taip pat ir Lietuvoje. Jai būdingi dažni ligos paūmejjimai, reikalaujantys stacionarinio gydymo, laikinas arba ilgalaikis darbingumo praradimas, dažnesnès mirtys. Nors sunki astma sudaro mažiausią dalị iš visu sergančiuju astma, tačiau sąlygoja didžiausias išlaidas, skirtas šiai ligai gydyti. Todèl sveikatos priežiūros specialistams, gydantiems šiuos pacientus, svarbu suprasti sunkios astmos problemas ir taikyti tinkamiausias priemones joms spręsti.

Sunkia astma serga iki 5 proc. visų astma sergančių asmenų. Nors tokie duomenys skelbiami pastaraisiais dešimtmečiais, tačiau tikslus sunkios astmos paplitimas nežinomas. Epidemiologinius tyrimus sunkina vartojami skirtingi sunkios astmos apibrèžimai bei diagnostikos kriterijai. Kritiškai vertinti skelbiamą sunkios astmos paplitimą verčia ir pasikeitęs supratimas apie astmos sunkumą, kontrolę, kuriems didelę įtaką turi vaistu vartojimas bei teisinga inhaliavimo technika.

Pastaraisiais metais keitèsi sunkios astmos supratimas, ị klinikinę praktiką ịdiegiami nauji vaistai sunkiai astmai gydyti, tapo aktualus sunkios astmos nustatymas ir individualaus gydymo parinkimas. Norint suprasti ir tinkamai diagnozuoti bei gydyti sunkią astmą, svarbu suvokti ir vartoti tinkamą terminologiją. Terminas „sunkiai gydoma astma" (angl. difficult-to-treat asthma) apibūdina astma sergančius pacientus, kuriems gerą astmos kontrolę trukdo pasiekti tokie veiksniai, kaip gretutinès ligos, netinkamas vaistų vartojimas arba ịvairūs išoriniai (aplinkos) veiksniai. Sunki astma apima sergančiuosius, kai astma išlieka nekontroliuojama, nepaisant intensyvaus adekvataus astmos ir gretutiniu ligu gydymo, todèl kartais dar vadinama „sunkia refrakterine astma“.

Sunki astma - tai astma, kurios gydymui per praejusius metus buvo reikalinga 4-5 gydymo pakopa pagal GINA (didele ikvepiamojo gliukokortikoido doze kartu su ilgo veikimo $\beta_{2}$ agonistu arba leukotrienu receptoriu antagonistu, arba teofilinu) arba per praejusius metus $\geq 50$ proc. laiko buvo vartojami sisteminiai gliukokortikoidai tam, kad astma būtu kontroliuojama, arba, nepaisant šio gydymo, astma išlieka nekontroliuojama.

Pirmoje lentelèje pateikiamos ekvivalentinès didelès ¡kvepiamųų gliukokortikoidų paros dozès suaugusiems asmenims pagal ERS/ATS rekomendacijas (2014). 


\section{Rekomendacijos}

Sunki astma nekontroliuojama, jei yra bent vienas iš žemiau pateiktų keturių kriterijų:

1. Bloga simptomy kontrole. Astmos kontrolès klausimynas (ACQ) > 1,5 balų arba Astmos kontrolès testas $($ ACT $)<20$ balų, arba astma nekontroliuojama pagal GINA kriterijus;

2. Dažni sunkūs astmos paūmèjimai. Per praejusius metus dèl astmos paūméjimų buvo skirti du ir daugiau gydymo sisteminiais gliukokortikoidais kursai (kiekvienas ilgesnis nei 3 dienų trukmès).

3. Labai sunkūs astmos paūmèjimai. Per praejusius metus ligonis bent vieną kartą buvo gydytas stacionare arba intensyviosios terapijos skyriuje, arba jam buvo reikalinga dirbtinè plaučių ventiliacija.

4. Bronchų obstrukcija. Nepavartojus bronchus plečiamojo vaisto, $\mathrm{FEV}_{1}<80$ proc. normos, esant $\mathrm{FEV}_{1} / \mathrm{FVC}$ mažiau apatinès normos ribos.

\section{SUNKIOS ASTMOS DIAGNOSTIKA}

Sunki astma diagnozuojama nuosekliai trimis etapais:

1) Astmos diagnozès patvirtinimas.

2) Gretutinių ligų ir sunkinančių veiksnių išaiškinimas.

3) Sunkios astmos ir jos fenotipo nustatymas.

\section{1 etapas. Astmos diagnozès patvirtinimas}

Diagnozuojant sunkią astmą, pirmiausia įvertinama, ar tikrai paciento klinikiniai, ligos istorijos, tyrimo duomenys atitinka astmos diagnozę. Klaidinga nekontroliuojamos sunkios astmos diagnozè pasitaiko 12-30 proc. atvejų.

Paciento tyrimas turi būti pradedamas nuo jo skundu ir ligos anamnezès išsiaiškinimo, atkreipiant dėmesi $\mathfrak{i}$ astmos simptomus, sunkinančius ir paūmejjimus provokuojančius veiksnius. Patvirtinant astmos diagnozę, svarbu patvirtinti ir dokumentuoti bronchų obstrukcijos kintamumą. Tam atliekami plaučių funkcijos tyrimai spirometrija, bronchų plètimo méginys, PEF-metrija (pagal astmos diagnostikos rekomendacijas). Kiti plaučių funkcijos tyrimai, pvz., dujų difuzijos tyrimas, bronchų provokaciniai mėginiai, prireikus, gali būti atlikti, kai yra santykinai gera plaučių funkcija, ypač kai nesutampa ligos anamnezès, objektyvaus tyrimo ir spirometrijos duomenys.

Svarbu pasireiškiančius klinikinius simptomus atskirti nuo kitų ligų ir būklių, kurios gali imituoti astmą ar būti su ja susiję (2 lentelè).

Tyrimai, kuriuos tikslinga atlikti ligoniams, sunkiai astmai ir kitoms ligoms diferencijuoti, pateikiami 3 lentelèje.

\section{2 etapas. Gretutinių ligų ir sunkinančių veiksnių išaiškinimas}

Siekiant optimalios astmos kontrolès, reikia ištirti gretutines ligas bei išsiaiškinti aplinkos ir kitus veiksnius, sunkinančius ligos eigą (4 lentelè).
1 lentelè. Didelès ịkvepiamujų gliukokortikoidụ paros dozès suaugusiems asmenims (pagal ERS/ATS, 2014)

\begin{tabular}{|l|l|}
\hline $\begin{array}{l}\text { lkvepiamasis } \\
\text { gliukokortikoidas }\end{array}$ & Paros doze mikrogramais \\
\hline $\begin{array}{l}\text { Beklometazono dipropio- } \\
\text { natas }\end{array}$ & $\begin{array}{l}\geq 2000 \text { (DMI ar CFC DAl) } \\
\geq 1000 \text { (HFA DAI) }\end{array}$ \\
\hline Budezonidas & $\geq 1600$ (MDI ar DMI) \\
\hline Ciklezonidas & $\geq 320$ (HFA DAl) \\
\hline Flutikazono propionatas & $\geq 1000$ (HFA DAl ar DMI) \\
\hline Mometazono furoatas & $\geq 800$ (DMI) \\
\hline Triamcinolono acetonidas & $\geq 2000$ \\
\hline
\end{tabular}

ERS - Europos respiratology draugija; ATS - Amerikos krūtinès draugija; DMI - dozuotu miltelių inhaliatoriai; CFC - chlorofluorokarbonas; DAI dozuoto aerozolio inhaliatoriai; HFA - hidrofluoralkanas.

\section{2 lentelè. Ligos ir klinikinès situacijos, kurias reikia dife-} rencijuoti nuo sunkios astmos

- Disfunkcinis dusulys, balso klosčių disfunkcija

- Lètinè obstrukcinè plaučių liga

- Hiperventiliacija su panikos priepuoliais

- Obliteruojantis bronchiolitas

- Stazinis širdies nepakankamumas

- Nepageidaujami vaistu reiškiniai, pvz., angiotenziną konvertuojančio fermento inhibitorių (AKFI) vartojimas

- Bronchektazès, cistinè fibrozé

- Hipersensityvinis pneumonitas (egzogeninis alerginis alveolitas)

- Hipereozinofilinis sindromas

- Plaučių embolija

- Virusinis tracheobronchitas

- Endobronchiniai pokyčiai (pvz., karcinoidas, trachejjos arba bronchu sriktūra, svetimkūnis)

- Alerginè bronchopulmoninè aspergiliozè

- Igyta tracheobronchomaliacija

AKFI - angiotenziną konvertuojančio fermento inhibitoriai.

Rinosinusitas diagnozuojamas 75-80 proc. sergančiųjų sunkia astma. Nosies polipai būna nedidelei daliai suaugusiųjų. Sergantieji sunkia astma turi būti tiriami dèl viršutinių kvèpavimo takų ligų, nes jų gydymas gali pagerinti astmos kontrolę.

Gastroezofaginio refliukso liga (GERL) sergantiesiems sunkia astma gali būti nustatoma iki $60-80$ proc. atvejų. Nors akivaizdžių klinikinių ịrodymų apie GERL gydymo naudą stinga, tačiau pacientams, kuriems sunki astma yra blogai kontroliuojama ir GERL yra simptominis tikslinga skirti priešrefliuksini gydymą.

Nutukimas yra dažna gretutinè sunkios astmos būklè. Sunki astma nutukusiems žmonèms nepakankamai kontroliuojama dèl gretutinių ligų (pvz., obstrukcinès miego apnèjos, GERL), fizinio pajègumo ir plaučiu tūrių sumažejimo (dèl pilvo riebalų). Nutukusiems, sergantiesiems sunkia astma gali būti sumažèjęs gydymo gliukokortikoidais poveikis. Šiems pacientams labai 


\section{Rekomendacijos}

3 lentelè. Tyrimai, kuriuos tikslinga atlikti ligoniams, sergantiems sunkia astma

\begin{tabular}{|c|c|c|}
\hline \multicolumn{2}{|l|}{ Tyrimai } & \multirow{2}{*}{$\begin{array}{l}\text { Pastabos } \\
\text { Esant neaiškios kilmės dusuliui, rūkaliams }\end{array}$} \\
\hline Funkcijų & Plaučių tūriai & \\
\hline & Dujų difuzija plaučiuose & Rūkaliams, vèlyva astmos pradžia \\
\hline & $\begin{array}{l}\text { Nespecifinis bronchų provokacijos mėginys } \\
\text { (metacholinas, fizinis krūvis ir pan.) }\end{array}$ & Esant normaliai arba beveik normaliai plaučių funkcijai \\
\hline & $\begin{array}{l}\text { Nosies azoto oksidas (NO), kvèpavimo taku } \\
\text { biopsinès medžiagos elektroninè mikrosko- } \\
\text { pija, cilijų judrumas ir funkcija }\end{array}$ & Itariant pirminę ciliarinę diskineziją \\
\hline & Fizinio krūvio pajėgumo mèginiai & Kai pacientas dūsta esant pakankamai plaučių funkcijai \\
\hline \multirow[t]{5}{*}{ Laboratoriniai } & $\begin{array}{l}\text { Aspergillus specifiniai lgE (svarstyti ir kitu } \\
\text { grybų) }\end{array}$ & $\begin{array}{l}\text { Kai padidejęş bendrojo IgE kiekis, yra centrinès bron- } \\
\text { chektazės arba eozinofilija kraujyje }\end{array}$ \\
\hline & Chloro kiekis prakaite & $\begin{array}{l}\text { Itariant cistinę fibrozę, esant bronchektazėms, mukociliarinio } \\
\text { klirenso sutrikimams, nevaisingumui, šeiminei anamnezei }\end{array}$ \\
\hline & $\begin{array}{l}\text { Antibranduoliniai citoplazminiai antikūnai } \\
\text { (ANCA) }\end{array}$ & $\begin{array}{l}\text { Itariant eozinofilinę granulomatozę su poliangitu ar kitą } \\
\text { vaskulitą }\end{array}$ \\
\hline & Genetiniai tyrimai & Itariant cistinę fibrozę, pirminę ciliarinę diskineziją \\
\hline & $\begin{array}{l}\text { Kotinino kiekis seilèse arba šlapime, karbok- } \\
\text { sihemoglobino (HbCO) kiekis kraujyje }\end{array}$ & Rūkymo faktui patvirtinti \\
\hline \multirow[t]{2}{*}{ Endoskopiniai } & Bronchoskopija & Paneigti kitoms ligoms \\
\hline & Fibrooptinè rinoskopija arba laringoskopija & Rinosinusitui, balso klosčiu disfunkcijai nustatyti \\
\hline \multirow[t]{2}{*}{ Radiologiniai } & Krūtinès ląstos kompiuterinè tomografija & $\begin{array}{l}\text { Itariant kitas plaučių ligas, esant pokyčiams krūtinès } \\
\text { ląstos rentgenogramoje }\end{array}$ \\
\hline & Prienosinių ančių kompiuterinè tomografija & Lètiniam sinusitui diagnozuoti \\
\hline Psichologiniai & Psichosocialinis, psichiatrinis j̨vertinimas & $\begin{array}{l}\text { Sergantiesiems astma, kuriems psichosocialiniai sutriki- } \\
\text { mai gali būti pirminiai }\end{array}$ \\
\hline
\end{tabular}

NO - azoto oksidas; IgE - imunoglobulinas E; ANCA - antibranduoliniai citoplazminiai antikūnai; HbCO - karboksihemoblobino.

4 lentelè. Gretutinès ligos ir sunkinantys veiksniai, susiję su sunkia astma

- Rinosinusitas, nosies polipai

- Psichologiniai veiksniai: individualios savybės, simptomy suvokimas, nerimas, depresija

- Balso klosčių disfunkcija

- Obstrukciné miego apnejja

- Hiperventiliacijos sindromas

- Hormony pokyčiai: premenstruacijos, menstruacijos, menopauzè, skydliaukès funkcijos sutrikimai, nèštumas

- Gastroezofaginio refliukso liga

- Vaistai: aspirinas, nesteroidiniai vaistai nuo uždegimo, beta adrenoblokatoriai, angiotenziną konvertuojančio fermento inhibitoriai

- Nutukimas

- Rūkymas arba su rūkymu susijusios ligos

- Netinkama vaistų ikvejpimo technika

- Vaistų vartojimo režimo nesilaikymas

- Isijautrinimas aplinkos alergenams ir toksinès medžiagos aplinkoje

svarbu mažinti kūno svorị ne tik didinant fizinị aktyvumą, bet ir kitomis priemonèmis (pvz., dieta ir kt.).

Nerimas ir depresija sergantiesiems sunkia astma nusta- tomi $25-49$ proc. atvejų. Dèl nerimo ir depresijos padažnëja astmos paūmèjimai bei vizitai ị skubiosios pagalbos skyrių. Be to, panikos ataką galima supainioti su astmos priepuoliu arba paūméjimu. Ittarus nerimo ir depresijos simptomus, pacientas turètų būti siunčiamas psichiatrui konsultuoti. Visgi, skiriant psichologinę pagalbą, apimančią ịvairias elgesio, relaksacijos technikas, teigiamo poveikio astmos kontrolei dažniausiai negaunama.

Visada reikia ịvertinti, ar pacientas laikosi vaistu vartojimo režimo, ar taisyklinga vaistų įkvèpimo technika. Vaistų vartojimo ịvertinimas yra sudètingas. Prednizolono, teofilino koncentracijos kraujyje tyrimas, sisteminių gliukokortikoidų sąlygoti nepageidaujami poveikiai ir kortizolio kiekio sumažejimas serume padeda ịvertinti geriamųjų vaistų vartojimą. Taip pat galima patikrinti likusių dozių skaičių inhaliatoriuje bei vaistų išrašymo duomenis. Jei patvirtinama, kad pacientas nevartoja medikamentų, gydytojas turètų mokyti apie astmą, jos eigą bloginančius veiksnius ir motyvuoti astma sergančiuosius vartoti jiems skirtus medikamentus.

Atopija ir alergija ilgą laiką buvo siejama su astma, ypač su sunkia astma. Kaip parodè didelès imties 


\section{Rekomendacijos}

5 lentelè. Sunkios astmos fenotipai ir jų požymiai

\begin{tabular}{|c|c|}
\hline Fenotipas & Požymiai \\
\hline Sunki alerginè astma & $\begin{array}{l}\text { Ankstyva ligos pradžia, šeiminè astmos anamnezè, atopija, dermatitas, nosies polipai, padidèjęs lgE } \\
\text { kiekis kraujo serume, padidejjęs FeNO kiekis iškvepiamame ore, eozinofilija kraujyje ir skrepliuose }\end{array}$ \\
\hline $\begin{array}{l}\text { Sunki eozinofilinè } \\
\text { astma }\end{array}$ & $\begin{array}{l}\text { Vèlyva ligos pradžia, nedaug simptomu, dažniau serga vyrai, pasikartojantys paūmèjimai, nosies polipai, } \\
\text { sinusitas, eozinofilija kraujyje ir skrepliuose, padidèjęs FeNO kiekis iškvepiamame ore, dažnai priklausomi } \\
\text { nuo sisteminiu gliukokortikoidu, kai kuriems gali būti aspirino sukelta kvėpavimo takų liga (ankščiau } \\
\text { taip vadinta „aspirininè astma“) }\end{array}$ \\
\hline $\begin{array}{l}\text { Sunki nutukusiujų } \\
\text { astma }\end{array}$ & $\begin{array}{l}\text { Vèlyva pradžia (50-60 metų amžiuje), dažniau serga moterys, nutukimas, padidèjęs kūno masès } \\
\text { indeksas, dažni paūmèjimai, dažnos gretutinès ligos (obstrukcinè miego apnèja, GERL) }\end{array}$ \\
\hline $\begin{array}{l}\text { Sunki astma su } \\
\text { nuolatine bronchy } \\
\text { obstrukcija }\end{array}$ & $\begin{array}{l}\text { Ankstyva pradžia, atopija, išreikšti simptomai, normalus KMI, padidejjęs bronchų hiperraktyvumas, } \\
\text { nuolatinè bronchų obstrukcija, sustorèjusi kvėpavimo takų sienelè, remodeliacija, perteklinis } \beta 2 \\
\text { agonistų vartojimas }\end{array}$ \\
\hline $\begin{array}{l}\text { Sunki neutrofilinè } \\
\text { astma }\end{array}$ & 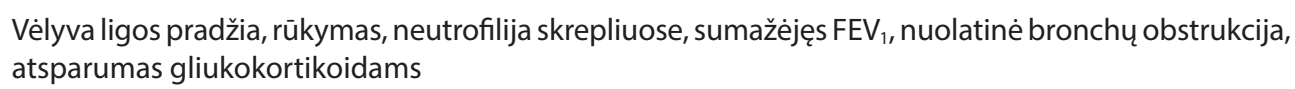 \\
\hline
\end{tabular}

IgE - imunoglobulinas E; FeNO - frakcinè iškvepiamo azoto oksido koncentracija; GERL - gastroezofaginio refliukso liga; KMI - kūno masès indeksas; $\mathrm{FEV}_{1}$ - forsuoto iškvèpimo greitis per pirmają sekundę.

epidemiologinių tyrimų rezultatai, sunki astma yra mažiau susijusi su atopija ir alergija nei lengvesnè astma. Nemažai pacientų, sergančių sunkia astma, yra įsijautrinę grybams, tokiems, kaip Aspergillus spp., Cladosporium spp., Alternaria spp., Penicillium spp., Candida spp., Trichophyton spp. ir kitiems. Ivertinus specifinių IgE kraujyje arba odos dūrio mèginių, provokuojančių alergenų ir simptomų ryšio prielaidas, galima méginti nustatyti veiksnius, turinčius ittakos astmos simptomams ir paūmejjimams.

Rūkymas blogina sunkios astmos kontrolę. Rūkant kinta kvépavimo takų uždegimo pobūdis, silpnèja gliukokortikoidų poveikis. Pasyvus rūkymas taip pat blogina astmos eigą. Ar pacientas rūko, galima nustatyti ištiriant kotininą šlapime arba seilèse bei karboksihemoglogino kiekị arteriniame kraujyje. Metus rūkyti, pagerejja astmos kontrolè.

Oro taršos mažinimo įtaka sunkios astmos kontrolei nepakankamai ištirta. Kaip rodo tyrimai, astmos baigtys pagerejo sumažejus transporto išmetamų dujų taršai miestuose.

\section{3 etapas. Sunkios astmos ir jos fenotipo nustatymas}

Sunkios astmos diagnozė patvirtinama tik po paciento specializuoto ištyrimo, pakankamos gydymo ir stebèsenos trukmès, paprastai trunkančios iki 3 mèn.

Patvirtinus sunkios astmos diagnozę, tiriama dèl jos fenotipo. Sunki astma yra nevienalytè liga, įvairi savo klinikiniu vaizdu, patofiziologiniais mechanizmais, gydomuoju poveikiu ir baigtimis. Paciento, sergančio sunkia astma, priskyrimas kuriam nors fenotipui ir individualaus gydymo taikymas gali pagerinti astmos eigą bei sumažinti vaistų nepageidaujamą poveiki. Kvėpavimo takų uždegimo tipas, alergija, nutukimas, amžius, kai prasidejjo astma, bronchų obstrukcija,
6 lentelè. Tyrimai, kuriuos tikslinga atlikti išskiriant sunkios astmos fenotipą

\begin{tabular}{|l|l|}
\hline Tyrimas & $\begin{array}{l}\text { Sunkios astmos } \\
\text { fenotipas }\end{array}$ \\
\hline Eozinofilų skaičius kraujyje & $\begin{array}{l}\text { Sunki eozinofiline astma } \\
\text { Sunki alergine astma }\end{array}$ \\
\hline $\begin{array}{l}\text { Indukuotų skreplių citologinis } \\
\text { tyrimas }\end{array}$ & $\begin{array}{l}\text { Sunki eozinofiline astma } \\
\text { Sunki neutrofiline astma } \\
\text { Sunki nutukusiujų astma }\end{array}$ \\
\hline $\begin{array}{l}\text { Bronchoalveolinio lavažo skys- } \\
\text { čio citologinis tyrimas }\end{array}$ & $\begin{array}{l}\text { Sunki eozinofiline astma } \\
\text { Sunki neutrofiline astma } \\
\text { Sunki nutukusiujų astma }\end{array}$ \\
\hline $\begin{array}{l}\text { Bendrojo ir specifiniu lgE kie- } \\
\text { kio nustatymas kraujyje }\end{array}$ & Sunki alerginė astma \\
\hline FeNO kiekis iškvepiamame ore & Sunki eozinofiline astma \\
\hline $\begin{array}{l}\text { Spirometrija su bronchu plè- } \\
\text { timo mėginiu, kūno pletizmo- } \\
\text { grafija, dujų difuzijos tyrimas }\end{array}$ & $\begin{array}{l}\text { Sunki astma su nuolatine } \\
\text { bronchų obstrukcija }\end{array}$ \\
\hline $\begin{array}{l}\text { Bronchu sienelės biopsija ir } \\
\text { morfologinis tyrimas }\end{array}$ & $\begin{array}{l}\text { Sunki astma su nuolatine } \\
\text { bronchų obstrukcija }\end{array}$ \\
\hline Rinoskopija & $\begin{array}{l}\text { Sunki alergine astma } \\
\text { Sunki eozinofiline astma }\end{array}$ \\
\hline
\end{tabular}

$\lg \mathrm{E}$ - imunoglobulinas $\mathrm{E}$; FeNO - frakcinè iškvepiamo azoto oksido koncentracija.

paūmejjimai, jautrumas gliukokortikoidams yra tie požymiai, pagal kuriuos gali būti išskirtas konkretus ligos fenotipas (5 lentelè).

Tyrimai, kurie padeda išskirti konkretų sunkios astmos fenotipą, pateikiami 6 lentelèje.

Žemiau pateikiamas sunkios astmos diagnostikos algoritmas (1 pav.).

Sunkios astmos diagnozè formuluojama pagal Lietuvos suaugusiujju astmos diagnostikos ir gydymo 


\section{Rekomendacijos}

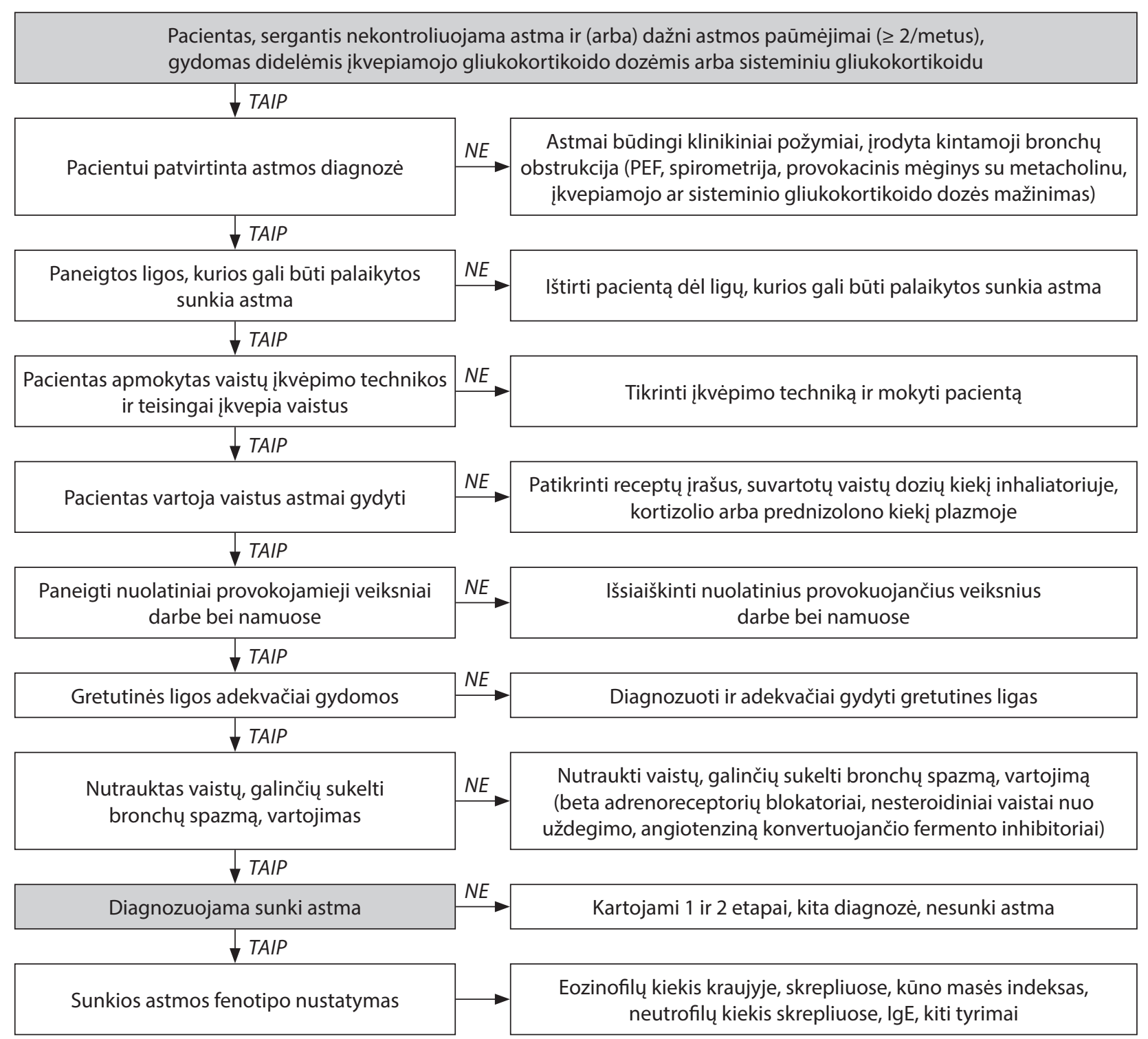

1 pav. Sunkios astmos diagnostikos algoritmas

sutarime (2015) pateiktas rekomendacijas. Sunkios astmos fenotipas diagnozèje nerašomas.

\section{SUNKIOS ASTMOS GYDYMAS}

Sunkios astmos gydymas apima ne vien vaistų vartojimą, bet visą kompleksą ilgalaikių priemonių, vartojamų šios ligos priežasčių, simptomų bei pasekmių prevencijai ir šalinimui. Dažnai, gydant sunkią astmą, prireikia daugiadisciplinès specialistų komandos. Paprastai ilgalaikis medikamentinis astmos gydymas remiasi periodišku simptomų kontrolès ir paūmèjimų rizikos vertinimo principu. Prieš sudarant sunkios astmos gydymo planą, pirmiausia reikia išsiaiškinti galimas visas kitas priežastis, dẻl kurių astmos gydymas gali būti neveiksmingas. Pagrindinis tikslas, gydant sunkią astmą, yra ligos paūmèjimų ir skubių hospitalizavimų retinimas, o ne visiška astmos simptomų kontrolè. Todèl, siekiant išvengti perteklinio vaistų vartojimo, vaistų perdozavimo ir jų sukeliamo nepageidaujamo poveikio, pacientams, sergantiems sunkia astma, gali tekti siekti tik dalinès astmos simptomų kontrolès.

\section{Vaistai sunkiai astmai gydyti}

İkepiamieji ir sisteminiai gliukokortikoidai. İkvepiamieji gliukokortikoidai yra pagrindiniai vaistai sunkiai astmai gydyti. Jie pasižymi uždegimą slopinamuoju poveikiu ir yra veiksmingi gydant daugeli sunkia astma sergančių pacientų. İkvepiamieji gliukokortikoidai palengvina astmos simptomus, pagerina plaučių funkciją, gyvenimo kokybę, sumažina bronchų hiperreaktyvumą, retina paūmèjimus.

\Łkvepiamųjų gliukokortikoidų dozės poveikio kreivè yra individuali, tačiau sergantiesiems sunkia astma veiksmingos gali būti tik didelès šių vaistų dozės. Kai astma išlieka nekontroliuojama, skiriant dideles i tkvepiamųjų gliukokortikoidų dozes, reiketų apsvarstyti ¡̇kvepiamųjų gliukokortikoidų dozès didinimą iki labai 


\section{Rekomendacijos}

didelių dozių (>2000 $\mu \mathrm{g} / \mathrm{d}$. beklometazono arba ekvivalentiška kito įkvepiamojo gliukokortikoido dozè) arba itin smulkių dalelių inhaliuojamojo gliukokortikoido skyrimą. Skiriant labai didelę ịkvepiamųju gliukokortikoidų dozę, padideja ir sisteminio nepageidaujamo poveikio rizika.

Kai, nepaisant gydymo didelemis ịkvepiamųjų gliukokortikoidų ir ilgo veikimo $\beta_{2}$ agonistų dozėmis arba kitu pridedamuoju vaistu, kas 2-3 ménesius prireikia trumpalaikių geriamųjų gliukokortikoidų kursų, reiktų apsvarstyti tikslingumą skirti mažas palaikomąsias geriamųjų gliukokortikoidų dozes. Dèl galimų sisteminių nepageidaujamų gliukokortikoidų poveikių palaikomąjam gydymui skiriama mažiausia veiksminga geriamojo gliukokortikoido dozè ir kaip įmanoma trumpesnị laiką. Ilgą laiką vartojami sisteminio poveikio gliukokortikoidai sukelia nepageidaujamų poveikių: kaulų lūžius, kataraktą, svorio priaugimą, cukrinị diabetą, arterinę hipertenziją. Svorio priaugimas ateityje gali sunkinti astmos kontrolę. Todèl nuolat vartojant sisteminius gliukokortikoidus ir dideles ikvepiamųju gliukokortikoidų dozes, nereikètų pamiršti stebèti svorio priaugimą, kraujospūdị, gliukozès kiekị kraujyje, regą, kaulų tankį.

Sunki astma dažnai apibūdinama kaip gliukokortikoidams atspari arba nejautri. Kad būtų palaikoma tam tikro lygio astmos kontrolè, iki 30 proc. sunkia astma sergančių asmenų be ịkvepiamųjų gliukokortikoidų reikia ir sisteminio poveikio gliukokortikoidų. Pacientai, kurių astmos kontrolei pasiekti reikia geriamųjų gliukokortikoidų, o būklè pablogèja juos sumažinus arba nutraukus, apibūdinami kaip priklausomi nuo geriamųjų gliukokortikoidų. Atsparumas gliukokortikoidams nèra nuolatinis ir susijęs su tam tikromis būklèmis, pvz., nutukimas, rūkymas, sumažèjęs vitamino D kiekis bei neutrofilinis kvėpavimo takų uždegimas.

Trumpo ir ilgo veikimo bronchus plečiamieji vaistai. Trumpo veikimo $\beta_{2}$ agonistai, dažniausiai salbutamolis, skiriami ūmiems astmos simptomams palengvinti. Perteklinis trumpo veikimo $\beta_{2}$ agonistu vartojimas susijęs su vaistų toksiškumu bei padidẻjusiu mirštamumu nuo astmos. Todèl jie skiriamai tik pagal reikalą simptomams palengvinti, bet ne nuolatiniam gydymui. Gydant sunkią astmą labai greitai pasiekiamos rekomenduojamos didžiausios vaistų dozes. Kai kuriems sunkia astma sergantiems pacientams simptomai labiau palengvejja trumpo veikimo bronchus plečiamuosius vaistus vartojant per purkštuvą.

Kaip alternatyva trumpai veikiančiam $\beta_{2}$ agonistui arba kartu su juo gali būti vartojami trumpo veikimo muskarino receptorių blokatoriai, pvz., ipratropio bromidas. Taip sumažinama $\beta_{2}$ agonistų paros dozé, išvengiama jų perdozavimo bei nepageidaujamo poveikio, pvz., galūnès - tremoro sutrikimo. Nors ipratropio bromidas yra mažiau veiksmingas, tačiau gerai toleruojamas.

Dažniausiai sunkia astma sergantys pacientai gydomi ikvepiamojo gliukokortikoido ir ilgo veikimo $\beta_{2}$ agonistu deriniu. Tačiau daliai šiuc pacientų vis tiek išlieka bronchų obstrukcija. Padidinta įkvepiamojo gliukokortikoido dozé, kartu su ilgo veikimo $\beta_{2}$ agonistu labiau pagerina astmos kontrolę nei vien ¡kvepiamojo gliukokortikoido vartojimas. Be to, kai kurių sunkia astma sergančių pacientų savijauta yra geresnè vartojant šį vaistų derinị, nors nèra pasiekiama optimali astmos simptomų kontrolè. Vien ilgo veikimo $\beta_{2}$ agonistas (be ikvepiamojo gliukokortikoido) dèl didesnès mirties rizikos neskiriamas astmai gydyti.

Ilgo veikimo îkvepiamojo muskarino receptorių blokatoriaus tiotropio bromido veiksmingumas patvirtintas, skiriant ji papildomai nuolatiniam gydymui sunkia astma sergantiems pacientams, kuriems nepavyko pasiekti pakankamos astmos kontrolès gydant didele ikvepiamojo gliukokortikoido doze kartu su ilgo veikimo $\beta_{2}$ agonistu. Kasdien ịkvepiant $5 \mu \mathrm{g}$ tiotropio, galima pagerinti ligos kontrolę ir suretinti astmos paūmejjimus, sumažinti trumpo veikimo $\beta_{2}$ agonistų poreikị, išvengti ịkvepiamųjų gliukokortikoidų dozès didinimo arba geriamųjų gliukokortikoidų vartojimo.

Teofilinas. Manoma, kad teofilinas padidina jautrumą gliukokortikoidams, tačiau tyrimų su sergančiaisiais sunkia astma neatlikta. Teofilinas pasižymi silpnesniu bronchus plečiamuoju poveikiu nei $\beta_{2}$ agonistai ir uždegimą slopinamuoju poveikiu nei ¡kvepiamieji gliukokortikoidai. Lètai atsipalaiduojantis teofilinas gali būti skiriamas kaip papildoma gydymo priemonè, kai gydymas ikvepiamaisiais gliukokortikoidais nepakankamai veiksmingas ir kai pacientas negali vartoti ilgo veikimo ịkvepiamųų $\beta_{2}$ agonistų.

Leukotrienų receptorių antagonistai. Sunkia astma sergantiems pacientams, kuriems vartojant dideles ¡kvepiamojo gliukokortikoido dozes ir ilgo veikimo $\beta_{2}$ agonistą, astma išlieka nekontroliuojama, rekomenduojama prideti leukotrienų receptorių antagonistus. Geresnis poveikis gaunamas, kai leukotrienų receptorių antagonistai skiriami sergantiesiems aspirino išprovokuota kvėpavimo takų liga (ankščiau vadinta aspirinine astma).

Makrolidai. Nors klinikiniai tyrimai parodè tam tikrą ilgalaikio makrolidų vartojimo veiksmingumą gydant sergančiuosius sunkia neutrofiline astma, tačiau, nesant patikimų įrodymų, jie nerekomenduojami.

Priešgrybiniai vaistai. Vaistai nuo grybų rekomenduojami sunkia astma sergantiesiems, kuriems kartojasi alerginès bronchopulmoninès aspergiliozès paūmejjimai. Šis gydymas suretina paūmejjimus ir sumažina simptomus. Nesant patvirtintai alerginès bronchopulmoninès aspergiliozès diagnozei, o tik ịsijautrinimui Aspergillus grybams, t. y. teigiamam odos 


\section{Rekomendacijos}

dūrio mèginiui arba padidejusiam specifinių IgE kiekiui kraujyje, gydymo vaistais nuo grybų neskiriama.

Biologiniai vaistai. Omalizumabas - monokloninis IgE antikūnas (anti-IgE), skiriamas sergantiesiems sunkia alergine astma kaip pridedamasis vaistas. Gydant omalizumabu, sumažeja astmos simptomai, paūmèjimų dažnis, ịkvepiamo gliukokortikoido dozè, skubios pagalbos medikamentų poreikis. Jei po 16 savaičių bandomojo gydymo astmos kontrolè nepagerèja, nesuretėja jos paūmèjimai, nepagerèja gyvenimo kokybè, mažai tikètina, kad tolesnis gydymas omalizumabu bus veiksmingas.

Mepolizumabas - monokloninis IL-5 antikūnas (anti-IL-5), kaip pridedamasis vaistas skiriamas sergantiesiems sunkia eozinofiline astma. Klinikiniai tyrimai parodè, kad, gydant sergančiuosius sunkia eozinofiline astma mepolizumabu, pagerèja gyvenimo kokybè, simptomų kontrolè, plaučių funkcija, sumažèja paūmèjimų skaičius, galima sumažinti geriamųjų gliukokortikoidų dozę.

Reslizumabas - monokloninis IL-5 antikūnas (anti-IL-5), kaip pridedamasis vaistas skiriamas sunkia eozinofiline astma sergantiems pacientams. Gydant reslizumabu, pagerejja sergančiųjų plaučių funkcija, gyvenimo kokybè, palengvejja astmos simptomai, retėja paūmejjimų dažnis.

Pacientai, kuriems palaikomąjam gydymui pirmą kartą skirti biologiniai vaistai (omalizumabas, mepolizumabas, reslizumabas), stebimi kas keturias savaites, o po 16 savaičių vertinamas gydymo klinikinis veiksmingumas. Toliau tęsiant gydymą biologiniu vaistu, pacientas kontrolei pas ši gydymą skyrusi gydytoją atvyksta ne rečiau kaip kas 6 mèn.

\section{Bronchų termoplastika}

Bronchų termoplastika - tai gydymo būdas, kai broncho sienele bronchoskopijos metu per specialuc prietaisą, išskiriantį radiodažnumines bangas, veikiama karščiu ir taip sumažinama astmos metu padidejusi bronchų lygiưjų raumenų masè. Dèl procedūros rizikos ir tik vidutinio klinikinio veiksmingumo, bronchų termoplastika atliekama tik gerai atrinktiems pacientams centruose, ịvaldžiusiuose šią metodiką. Lietuvoje šis sunkios astmos gydymo metodas dar nenaudojamas.

\section{Sunkios astmos gydymas atsižvelgiant ị fenotipą}

Dažnai sunkia astma sergančiu pacientų astma išlieka nekontroliuojama, nepaisant sudètinio gydymo plano, gretutinių ligų gydymo, provokuojančių ir sunkinančių veiksnių vengimo. Paciento, sergančio sunkia astma, priskyrimas kuriam nors fenotipui ir individualaus gydymo pritaikymas gali pagerinti astmos eigą bei sumažinti vaistų nepageidaujamą poveikį. Gydymas omalizumabu atvèrè individualizuoto sunkios astmos gydymo galimybę. Tačiau numatyti,
7 lentelè. Sunkios astmos pridedamasis gydymas remiantis fenotipu

\begin{tabular}{|l|l|}
\hline Fenotipas & Gydymas \\
\hline Sunki alergine astma & $\begin{array}{l}\text { Anti-lgE vaistas (omalizuma- } \\
\text { bas) }\end{array}$ \\
\hline Sunki eozinofilinė astma & $\begin{array}{l}\text { Anti IL-5 vaistas (mepolizu- } \\
\text { mabas, reslizumabas) }\end{array}$ \\
\hline Sunki nutukusiuju astma & Svorio mažinimas \\
\hline $\begin{array}{l}\text { Sunki astma su nuolatine } \\
\text { bronchų obstrukcija }\end{array}$ & $\begin{array}{l}\text { Ilgai veikiantis muskarino } \\
\text { receptoriu blokatorius } \\
\text { Bronchų termoplastika }\end{array}$ \\
\hline Sunki neutrofilinè astma & Makrolidas* \\
\hline
\end{tabular}

IgE - E klasès imunoglobulinas; IL-5 - interleukinas 5; * - veiksmingumas neirodytas.

kuriems pacientams gydymas bus veiksmingas, sudètinga, reikalingas bandomasis gydymo laikotarpis. Paremtas naujausiais klinikinių tyrimų duomenimis, pridedamasis sunkios astmos gydymas pagal fenotipus pateikiamas 7 lentelèje.

Sunkios astmos gydymo galimybių apibendrinimas pateikiamas 8 lentelèje.

\section{Pagalbos organizavimas sergantiesiems sunkia astma}

Sunkia astma sergantys pacientai paprastai turi ilgą ligos istoriją, serga gretutinèmis ligomis, vartoja dideles įkvepiamųjų gliukokortikoidų dozes, epizodiškai arba nuolat geriamuosius gliukokortikoidus, galinčius sukelti nepageidaujamus reiškinius, patiria dažnus ir sunkius ligos paūmèjimus. Sunkios astmos, gretutinių ligų, komplikacijų diagnostikai reikia specializuotų kvépavimo sistemos tyrimų (pvz., bronchoskopijos, bronchoalveolinio lavažo ir kt.). Šiems pacientams gali išsivystyti sunkūs, netgi gyvybei pavojingi astmos paūmèjimai, kurių metu būtinas intensyvus stacionarinis gydymas (taip pat ir neinvazinè arba invazinè dirbtiné plaučių ventiliacija). Daugumoje Europos šalių sunki astma diagnozuojama ir pacientai gydomi specializuotuose sunkios astmos centruose, koordinuojant tinkamą kompetenciją turintiems gydytojams pulmonologams.

Lietuvoje rekomenduojame, kad sunkia astma sergantys pacientai būtų tiriami, patvirtinant (paneigiant) sunkios astmos diagnozę, skiriamas gydymas ir stebėsena universitetų ligoninių pulmonologijos klinikos (pulmonologijos ir alergologijos centro) sunkios astmos centre ar kitam funkciniam padalinyje. Esant indikacijų, sunkios astmos centre šiuos pacientus konsultuoja ir kitų specialybių gydytojai bei kiti specialistai (alergologas ir klinikinis imunologas, ausų nosies gerklès gydytojas, gastroenterologas, dietologas, kardiologas, endokrinologas, chirurgas, psichiatras, logopedas, psichologas). 


\section{Rekomendacijos}

8 lentelè. Sunkios astmos gydymo galimybių santrauka

\section{Sunkios astmos gydymas}

lkvepiamieji gliukokortikoidai (IGK) išlieka pagrindiniais vaistais sunkiai astmai gydyti

Kiti gydymo variantai gali būti:

Optimizuoti IGK/IVBA dozę: kai kuriems pacientams teigiamą atsaką galima gauti skiriant didesnes nei iprastai IGK dozes. Tačiau toks gydymas didina sisteminių nepageidaujamų reiškinių riziką. Pasiekus optimalią vaistų doze, ji turi būti mažinama lètai, kas 6-3 mèn.

Geriamieji gliukokortikoidai (GGK): kai kuriais sunkios astmos atvejais yra veiksmingas palaikomasis gydymas mažomis GGK dozèmis. Pacientai turi būti stebimi dèl GGK nepageidaujamų poveikių ir laiku pradèti juos gydyti

Papildomas gydymas kontroliuojamaisiais vaistais neatsižvelgiant i fenotipq: pacientams, kuriems išliko nekontroliuojami simptomai ir nuolatinè bronchu obstrukcija, nepaisant gydymo didelèmis IGK dozèmis ir IVBA, papildomai skirti ilgo veikimo muskarino receptorių blokatorių arba leukotirenų receptorių antagonistą, arba teofiliną

Papildomas gydymas kontroliuojamaisiais vaistais atsižvelgiant i fenotipq: pacientams, sergantiems sunkia alergine astma ir padidejjusiu IgE kiekiu, gali būti veiksmingas gydymas anti-IgE vaistu, sunkia eozinofiline astma - anti-IL-5 vaistu, esant aspirino išprovokuota kvèpavimo takų ligai (aspirininei astmai) - leukotrienų receptorių antagonistu

Nefarmakologinis gydymas: bronchų termoplastika gali būti veiksminga selektyviai atrinktiems pacientams; psichologinė pagalba

IGK - jkvepiamasis gliukokortikoidas; IVBA - ilgo veikimo įkvepiamasis $\beta_{2}{ }^{-}$agonistas; GGK - geriamasis gliukokortikoidas; lgE - E klasès imunoglobulinas; IL-5 - interleukinas 5.

Svarbiausi šių centrų uždaviniai:

- Patvirtinti sunkios astmos diagnozę.

- Itarti ligas arba būkles, kurios imituoja sunkiai gydomą astmą arba ịtakoja astmos eigą (pvz., obstrukcinè miego apnejja, GERL ir kitos).

- Gydyti gretutines ligas ir būkles, prireikus siųsti pacientą konsultuoti atitinkamam specialistui.

- Parinkti pacientui individualizuota gydymą.

- Mokyti sergantiji sunkia astma.

Indikacijos konsultacijai sunkios astmos centre pateikiamos 9 lentelèje.

Centre patvirtinus sunkios astmos diagnozę ir skyrus pacientui gydymą, jo būklè stebima kas 1-3 mèn., kiekvieno vizito metu ịvertinant astmos kontrolès lygit, plaučių funkciją, vaistų vartojamumą ir įkvépimo techniką, nepageidaujamą vaistų poveikį. Pasiekus ligos kontrolę, sunkia astma sergantis pacientas toliau stebimas ir gydomas gydytojo pulmonologo arba gydytojo alergologo ir klinikinio imunologo arba šeimos gydytojo kas 6 mèn. siunčiant konsultuoti ị sunkios astmos centrą.

\section{LITERATŨRA}

1. Albert W, Wu AW, Skinner EA, Markson L, Clark RD, McDonald RC, et al. Treatment patterns among adult patients with asthma factors associated with overuse of inhaled $\beta$-agonists and underuse of inhaled corticosteroids. Arch Intern Med. 1999; 159(22):2697-704.

2. Amelink M, Hashimoto S, Spinhoven Ph, Pasma HR, Sterk PJ, Bel EH, et.al. Anxiety, depression and personality traits in severe, prednisone-dependent asthma. Respir Med. 2014; 108(3):438-44

3. Bel EH, Sousa A, Fleming L, Bush A, Chung KF, Versnel J, et al. Diagnosis and definition of severe refractory asthma: an international consensus statement from the Innovative Medicine Initiative (IMI). Thorax. 2011; 66(10):910-17.

\section{9 lentelè. Indikacijos konsultacijai sunkios astmos centre}

- Astma nekontroliuojama, vartojant didelę jkvepiamojo gliukokortikoido dozę su ilgo veikimo $\beta_{2}$ agonistu arba leukotrienų receptorių antagonistu, arba teofilinu.

- Per praejjusius metus $\geq 50$ proc. laiko buvo vartojami sisteminiai gliukokortikoidai.

- Sergantieji astma, vartojantys tris kontroliuojamuosius vaistus (taip pat didelę ikvepiamojo gliukokortikoido dozę).

- Pasireiškia dažni astmos paūmèjimai (du ir daugiau per metus), kurių gydymui buvo skirti sisteminiai gliukokortikoidai ilgiau nei tris dienas.

- Buvo gyvybei pavojingas astmos paūmèjimas (gydytas intensyviosios terapijos skyriuje arba jam buvo skirta dirbtinè plaučių ventiliacija), vartojant didelę įkvepiamojo gliukokortikoido dozę.

4. Bel EH, Wenzel SE, Thompson PJ, Prazma ChM, Keene ON, Yancey SW. Oral glucocorticoid-sparing effect of mepolizumab in eosinophilic asthma. N Engl J Med. 2014; 371(13):1189-97.

5. Brusselle GG, Maes T, Bracke KR. Eosinophilic airway inflammation in nonallergic asthma. Nat Med. 2013; 19(8):977-9.

6. Chung KF, Wenzel SE, Brozek JL, Bush A, Castro M, Sterket PJ, et al. International ERS/ATS guideliness on definition, evaluation and treatment of severe asthma. Eur Respir J. 2014; 43(2):343-73. Erratum in: Eur Respir J. 2014; 43(4):1216.

7. Chung KF. New treatments for severe treatment-resistant asthma: targeting the right patient. Lancet Respir Med. 2013; 1(8):639-52.

8. Dias-Ju'nior SA, Reis M, de Carvalho-Pinto RM, Stelmach R, Halpern A, Cukier A. Effects of weight loss on asthma control in obese patients with severe asthma. Eur Respir J. 2014; 43(5):1368-77.

9. Dweik RA, Boggs PB, Erzurum SC, Irvin CG, Leigh MW, Lundberg JO, et al. An official ATS clinical practice guideline: interpretation of exhaled nitric oxide levels (FeNO) for clinical applications. Am J Respir Crit Care Med. 2011; 184(5):602-15.

10. Fajt ML, Wenzel SE. Asthma phenotypes and the use of biologic medications in asthma and allergic disease: the next steps toward personalized care. J Allergy Clin Immunol. 2015; 135(2):299-310. 


\section{Rekomendacijos}

11. Fleming L, Wilson N, Regamey N, Bush A. Use of sputum eosinophil counts to guide management in children with severe asthma. Thorax. 2012; 67(3):193-8.

12. Gevaert P, Calus L, Van Zele T, Blomme K, De Ruyck N, Bauters W, et.al. Omalizumab is effective in allergic and nonallergic patients with nasal polyps and asthma. J Allergy Clin Immunol. 2013; 131(1):110-6.e1.

13. Global initiative for asthma. Global Strategy for Asthma Management and Prevention, Revised 2017. Available at: http:// www.ginasthma.com.

14. Haldar P, Pavord ID, Shaw DE, Berry MA, Thomas M, Brightling CE, et al. Cluster analysis and clinical asthma phenotypes. Am J Respir Crit Care Med. 2008; 178(3):218-24.

15. Hekking PPW, Wener RR, Amelink M, Zwinderman AH, Bouvy ML, Bel EH. The prevalence of severe refractory asthma. J Allergy Clin Immunol. 2015; 135(4):896-902.

16. Ismaila AS, Sayani AP, Marin M, Su Z. Clinical, economic, and humanistic burden of asthma in Canada: a systematic review. BMC Pulm Med. 2013; 13:70.

17. Kerstjens HA, Disse B, Schröder-Babo W, Bantje TA, Gahlemann M, Sigmund R, et al. Tiotropium improves lung function in patients with severe uncontrolled asthma: a randomized controlled trial. J Allergy Clin Immunol. 2011; 128(2):308-14

18. Kerstjens HA, Engel M, Dahl R, Paggiaro P, Beck E, Vandewalker $\mathbf{M}$, et al. Tiotropium in asthma poorly controlled with standard combination therapy. N Engl J Med. 2012; 367(13):1198-207.

19. Moore WC, Bleecker ER, Curran-Everett D, Erzurum SC Ameredes BT, Bacharier L, et al. Characterization of the severe asthma phenotype by the National Heart, Lung, and Blood Institute's Severe Asthma Research Program. J Allergy Clin Immunol. 2007; 119(2):405-13.

20. Moore WC, Meyers DA, Wenzel SE, Teague WG, Li H, Li X, et al. Identification of asthma phenotypes using cluster analysis in the Severe Asthma Research Program. Am J Respir Crit Care Med. 2010; 181(4):315-23.

21. National Asthma Education and Prevention Program: Expert panel report III: Guidelines for the diagnosis and manage- ment of asthma. Bethesda: National Heart, Lung, and Blood Institute; 2007. Available at: www.nhlbi.nih.gov/guidelines/ asthma/asthgdln.htm.

22. Oborne J, Mortimer K, Hubbard RB, Tattersfield AE, Harrison TW. Quadrupling the dose of inhaled corticosteroid to prevent asthma exacerbations: a randomized, double-blind, placebo-controlled, parallel-group clinical trial. Am J Respir Crit Care Med. 2009; 180(7):598-602.

23. Ortega HG, Liu MC, Pavord ID, Brusselle GG, FitzGerald JM, Chetta A, et. al Mepolizumab treatment in patients with severe eosinophilic asthma. N Engl J Med. 2014; 371(13):1198 207.

24. Reddel HK, Taylor DR, Bateman ED, Boulet LP, Boushey HA, Busse WW, et al. An official American Thoracic Society/ European Respiratory Society statement: asthma control and exacerbations: standardizing endpoints for clinical asthma trials and clinical practice. Am J Respir Crit Care Med. 2009; 180(1):59-99.

25. Robinson DS, Campbell DA, Durham SR, Pfeffer J, Barnes PJ, Chung KF. Systematic assessment of difficult-to-treat asthma. Eur Respir J. 2003; 22(3):478-83.

26. Sakalauskas R, Danila E, Malakauskas K, Zablockis R, Bagdonas A, Biekšiené, ir kt. Lietuvos suaugusiujų astmos diagnostikos ir gydymo sutarimas 2015. (Astmos diagnostikos ir gydymo rekomendacijos). Prieiga per internetą: http://www. pulmoalerg.lt.

27. ten Brinke A, Zwinderman AH, Sterk PJ, Rabe KF, Bel EH. Factors associated with persistent airflow limitation in severe asthma. Am J Respir Crit Care Med. 2001; 164(5):744-8.

28. Thomson NC, Chaudhuri R. Omalizumab: clinical use for the management of asthma. Clin Med Insights Circ Respir Pulm Med. 2012; 6:27-40.

29. Wenzel SE. Asthma phenotypes: the evolution from clinical to molecular approaches. Nat Med. 2012; 18(5):716-25.

30. Zazzali JL, Broder MS, Omachi TA, Chang E, Sun GH, Raimundo K. Risk of corticosteroid-related adverse events in asthma patients with high oral corticosteroid use. Allergy Asthma Proc. 2015; 36(4):268-74. 